Flight to Safety from European Stock Markets

Nektarios Aslanidis and Charlotte Christiansen

CREATES Research Paper 2017-38 


\title{
Flight to Safety from European Stock Markets*
}

\author{
Nektarios Aslanidis ${ }^{\dagger}$ \\ Universitat Rovira i Virgili, CREIP \\ Charlotte Christiansen ${ }^{\ddagger}$ \\ CREATES, Aarhus University
}

November 3, 2017

\footnotetext{
${ }^{*}$ The authors are grateful for helpful comments from .... Aslanidis acknowledges support from the Spanish Ministry of Science and Innovation project grant (Reference $\mathrm{N}^{o}$ ECO2016-75410-P). Christiansen acknowledges support from CREATES funded by the Danish National Research Foundation (DNRF78) and from the Danish Council for Independent Research, Social Sciences (DFF - 4003-00022).

${ }^{\dagger}$ Universitat Rovira i Virgili, Department d'Economia, CREIP, Avinguda Universitat 1, 43204 Reus, Spain. Email: nektarios.aslanidis@urv.cat.

${ }^{\ddagger}$ CREATES, Department of Economics and Business Economics, School of Business and Social Sciences, Aarhus University, Fuglesangs Alle 4, 8210 Aarhus V, Denmark. Email: CChristiansen@econ.au.dk. Lund University.
} 


\title{
Flight-to-Safety from European Stock Markets
}

\begin{abstract}
This paper investigates flight-to-safety from stocks to bonds in seven European markets. We use quantile regressions to identify flightto-safety episodes. The simple risk-return trade-off on the stock markets is negative which is caused by flight-to-safety episodes: During normal periods, the risk-return trade-off is positive and during flight-to-safety episodes it is negative. The effects of flight-to-safety episodes on the risk-return trade-off are qualitatively similar for own country flight-to-safety episodes, for flight from own country stock market to the US bond market, and for US flightto-safety. The strength of the trade-off is strongest for own country flightto-safety episodes. The risk-return trade-off is not significantly influenced by recession periods or the recent sovereign debt crisis. The main results hold for flight to gold instead of to bonds.
\end{abstract}

Keywords: flight-to-safety; risk-return trade-off; European markets; stock market; bond market; gold futures

JEL Classifications: C58, F30, G11, G15 


\section{Introduction}

This paper investigates flight-to-safety from stocks to bonds in seven European markets. To this end, we adopt a quantile regression approach to identify flight-to-safety episodes. Our results show evidence that accounting for flight-to-safety is important in the analysis of the intertemporal risk-return trade-off in European stock markets. Further, we show that flight-to-safety to gold rather than to bonds has similar effects on the risk-return trade-off in European stock markets.

In recent years, there has emerged a burgeoning literature on flight-tosafety, as initiated by Vayanos (2004). Authors have applied a range of methodologies in measuring flight-to-safety, e.g., Baur and Lucey (2009), Bekaert, Engstrom, and Xing (2009), and Baele, Bekaert, Inghelbrecht, and Wei (2015). Following the literature and in particular Baele, Bekaert, Inghelbrecht, and Wei (2015), we consider flight-to-safety as episodes that involve large positive bond market returns at the same time as large negative stock market returns. Differently to Baele, Bekaert, Inghelbrecht, and Wei (2015), we adopt quantile regressions to identify the flight-to-safety episodes. This approach is similar in spirit to earlier work on the stock-bond correlation quantiles by Aslanidis and Christiansen (2014). Another important difference to Baele, Bekaert, Inghelbrecht, and Wei (2015) is that we also investigate the risk-return trade-off in stocks accounting for the flight-tosafety. Further, we contribute to the literature by investigating differences between flight-to-safety from own country stocks to own country bonds, and flight from own country stocks to US bonds, and flight-to-safety from US stocks to US bonds.

The idea of identifying flight-to-safety through quantile regressions is explored by Ghysels, Plazzi, and Valkanov (2016) although with a different procedure: they use mixed data sampling (MIDAS) volatility. Ghysels, Plazzi, and Valkanov (2016) show that the risk-return relation is positive 
over tranquil periods that exclude FTS episodes (say the recent financial crisis). However, they focus exclusively on the US market. Instead, we consider a group of European markets and define flight-to-safety in relation to information obtained from the individual European markets as well as from the US market.

In a similar spirit to Ghysels, Plazzi, and Valkanov (2016), Ghysels, Guerin, and Marcellino (2014) show evidence of regime changes in the riskreturn trade-off by adopting a Markov-switching MIDAS approach. One of the regimes is given the interpretation of a flight-to-safety regime, although it is not explicitly identified as we do in the current paper.

Another strand of the literature investigate the hypothesis that gold represents a safe heaven asset. For instance, Baur and McDermott (2010) show that gold is a strong safe heaven for most developed markets during the recent financial crisis. The role of gold as a safe heaven asset is also confirmed by Ciner, Gurdgiev, and Lucey (2013) for the US and the UK. Following this line of research, we also consider flight-to-safety from stocks to gold, instead of bonds.

Other related papers such as Cao and Galvani (2016) seek to establish a link between momentum strategies with flight-to-safety. The main finding is that there are larger momentum profits during flight-to-safety episodes. Finally, Lettau and Ludvigson (2010) argue for a positive risk-return relation once lagged return and lagged volatility are taken into account. Instead, we focus on the unconditional risk-return trade-off.

The main results of the paper are as follows. The simple risk-return trade-off on the European stock markets is negative. The negative trade-off is caused by flight-to-safety episodes: During normal periods (i.e. in periods outside flight-to-safety episodes), the risk-return trade-off relation is positive, though not always significant. On the other hand, during flightto-safety episodes the aforementioned relation becomes significantly nega- 
tive. The effects of flight-to-safety episodes on the risk-return trade-off are qualitatively similar across definitions of flight-to-safety episodes; namely own country flight-to-safety episodes, flight from own country stock market to the US bond market, and US flight-to-safety episodes. The strength of the trade-off is strongest for own country flight-to-safety episodes. The risk-return trade-off on the European stock markets are not significantly influenced by recession periods or by the recent sovereign debt crisis. When considering flight-to-safety to gold instead of to bonds, the main results hold although the explanatory power of the regressions drops.

The remaining part of the paper is organized as follows: Section 2 discusses the data on the stock and bond markets. In Section 3, we define the flight-to-safety episodes. Section 4 presents the main results of the riskreturn trade-off and shows the effect of the flight-to-safety. Section 5 contains the flight-to-gold results. Finally, in Section 6 we conclude.

\section{European stock and bond returns}

We consider seven large European countries, namely, France, Germany, Italy, the Netherlands, Spain, Sweden, and the UK, in addition to the US. The sample period is from May 1991 through December 2016.

We use the DataStream stock market total return indices and the DataStream 10-year benchmark government bond total return indices measured in local currencies.

Initially, we use daily stock and bond returns to obtain the monthly flight-to-safety (FTS) indicators, more details on the FTS calculations follow below. In the empirical analysis, we use monthly stock returns and realized volatilities. The monthly realized volatility is the square root of the sum of the daily squared returns, similar to Viceira (2012).

[Insert Table 1] 
Table 1 shows the descriptive statistics of the stock returns and realized volatilities. The stock returns are much larger than the realized volatilities, e.g. for the UK the average stock return is 0.69 and the average realized volatility is 4.28 . In contract, the variations in the stock returns are relatively smaller than for the realized volatility.

\section{Flight-to-safety in European markets}

In the section we first identify the flight-to-safety (FTS) episodes and then we describe the FTS episodes across countries.

\subsection{Definition of flight-to-safety}

\subsubsection{Own country flight-to-safety}

Flight-to-safety is defined as when there is large positive bond returns and large negative stock returns at the same time. For own country FTS episodes we consider country $i$ 's bond market and country $i$ 's stock market. We consider a variable $\left(y(i, i)_{\tau}\right)$ that measures country $i^{\prime}$ s bond return (referring to the first $i$ ) minus country $i$ 's stock return on day $\tau$ :

$$
y(i, i)_{\tau}=r_{i \tau}^{b}-r_{i \tau}^{s}
$$

where $r_{i \tau}^{b}$ and $r_{i \tau}^{s}$ are the bond and stock returns for country $i$ at day $\tau$. When $y(i, i)_{\tau}$ is very large there is an indication of flight-to-safety. Following Ghysels, Plazzi, and Valkanov (2016) we run quantile regressions of $y(i, i)_{\tau}$ on five lags of the absolute stock and bond returns, and consider the $95 \%$ percentile. That is, when $y(i, i)_{\tau}$ exceeds the $95 \%$ percentile of the conditional quantile, then the daily flight-to-safety indicator equals one.

The monthly flight-to-safety variable $\left(F T S(i, i)_{t}\right)$ measures the proportion of days in month $t$ that country $i$ experiences such own country flightto-safety episodes. 


\subsubsection{US-European flight-to-safety}

We also consider flight-to-safety from the European stock markets to the US bond market rather than to their own bond market. This is new to the literature. Here we use one-day lagged US bond returns to account for time differences in trading hours: $y(U S, i)_{\tau}=r_{U S, \tau-1}^{b}-r_{i \tau}^{s}$. As before, the daily flight-to-safety indicator is equal to one when the conditional quantile exceeds the $95 \%$ percentile in the quantile regression on lags of the absolute returns (for the US bond returns we use lags two to six).

Similarly, FTS $(U S, i)_{t}$ is defined as the monthly US-country $i$ flight-tosafety (FTS) variable that measures the proportion of days in month $t$ with a US-European FTS episode.

\subsection{Empirical flight-to-safety episodes}

[Insert Table 2]

Table 2 shows the descriptive statistics of the FTS variables, $F T S(i, i)$ and $F T S(U S, i)$. On average around $5 \%$ of the days in a given month are FTS episodes. The sample statistics are similar for the own country $(F T S(i, i))$ and the US-European $(F T S(U S, i))$ flight-to-safety variables. Further, the sample statistics of the FTS variables vary only little across countries.

\section{[Insert Figure 1]}

Figure 1 shows the time series of the $F T S(i, i)$ variables. There is a lot of variation over the sample period. The FTS episodes appear not to be long lasting.

\section{[Insert Table 3]}

Table 3 shows correlations between the FTS variables. For each country the correlation between the own country and US-European FTS variables 
are fairly high, ranging from 0.68 for Spain to 0.78 for the Netherlands. Still, the correlation is far from perfect.

The correlation coefficients between the flight-to-safety for the US (FTS $(U S, U S))$ and the European markets $(F T S(i, i))$ are provided in the right most column. Here the correlation is relatively low, ranging from 0.53 for Italy to 0.67 for Germany. So, it would appear that it is important which flightto-safety episodes are used when investigating their empirical effects on the risk-return trade-off on the European stock markets.

We conduct pair wise Granger causality tests between the FTS US,US) and each of the $\operatorname{FTS}(i, i)$ variables based on 12 lags, cf. Granger (1969) (not tabulated). There is evidence of Granger causality from the US FTS variable to all of the European own country FTS variables, but not vice versa. So, the US FTS episodes Granger cause the European countries FTS episodes.

\section{Risk-return trade-off for European stock mar- kets}

In this section, we investigate the risk-return trade-off in the European stocks markets accounting for flight-to-safety episodes. All the results are provided in Table 4.

[Insert Table 4]

\subsection{Simple risk-return trade-off}

We regress the monthly stock returns on the monthly realized volatility using OLS and provide the $t$-statistics based on Newey and West (1987) standard errors. $R_{i t}$ and $V_{i t}$ are the return and volatility, respectively, on stock market $i$ during month $t$ :

$$
R_{i t}=c_{0}+c_{1} V_{i t}+e_{i t}
$$


The first two columns of Table 4 show that the simple risk-return tradeoff is negative and significant for all countries. The explanatory power of these regressions is fairly low (the adjusted $R$-squared ranges from 0.09 for Italy to 0.24 for the Netherlands).

\subsection{Flight-to-safety influence on risk-return trade-off}

We now investigate if the risk-return trade-off varies across FTS episodes and other periods. We consider differences between using own country, USown country, and US FTS episodes. Thus, we include the FTS variable and the FTS variable multiplied with the realized volatility. We extend the simple risk-return regression in the following manner:

$$
\begin{aligned}
& R_{i t}=c_{0}+c_{1} V_{i t}+c_{2} F T S(i, i)+c_{3} F T S(i, i)_{t} V_{i t}+e_{i t} \\
& R_{i t}=c_{0}+c_{1} V_{i t}+c_{2} F T S(U S, i)_{t}+c_{3} F T S(U S, i)_{t} V_{i t}+e_{i t} \\
& R_{i t}=c_{0}+c_{1} V_{i t}+c_{2} F T S(U S, U S)_{t}+c_{3} F T S(U S, U S)_{t} V_{i t}+e_{i t}
\end{aligned}
$$

Eq. (3) uses the own country flight-to-safety variable, eq. (4) uses the own country to US flight-to-safety variable, and eq. (5) uses the US flightto-safety variable. The results are shown in Table 4, where columns 3-4 report the results for eq. (3), columns 5-6 report the results for eq. (4), and columns 7-8 report the results for eq. (5).

Interestingly, the coefficient on the volatility $\left(c_{1}\right)$ turns from significantly negative in eq. (2) to positive in eq.'s (3) to (5) (but not significant, except for Germany and Italy). Although the specific results may differ across choice of FTS variable, they point to the same direction. That is, the riskreturn trade-off is generally not significant during non-FTS periods. During FTS episodes, the trade-off is significantly negative $\left(\widehat{c}_{3}<0\right)$ and much larger in absolute size than $\widehat{c}_{1}$. This applies to all countries and no matter 
which FTS variable is being used. Thus, it appears that the negative riskreturn trade-off is caused by FTS episodes. So, it is the unusual periods of flight-to-safety episodes that cause the seemingly strange negative riskreturn trade-off.

As seen, the explanatory power is much larger when accounting for FTS episodes; for eq. (3) the adjusted $R$-squared ranges between 0.29 (Spain and the UK) and 0.45 (Sweden). The explanatory power is largest when using own country FTS (France, the Netherlands, and Sweden) or US-European FTS (Germany, Italy, Spain, and the UK) and typically lowest for US FTS (except for France and Italy).

\subsection{Recession influence on risk-return trade-off}

[Insert Figure 2]

We now compare the role of FTS episodes to the CEPR recession periods. CEPR identifies the business cycle turning points for the euro countries. We implicitly assume that the recession periods for the UK are similar to those of the euro countries. We consider the example of Germany for illustration. Figure 2 plots the German FTS variable together with the CEPR recession indicator. The two variables are only weakly related (correlation coefficient is 0.08). Next, we consider the effects of CEPR recessions on the risk-return trade-off by running the following regressions:

$$
R_{i t}=c_{0}+c_{1} V_{i t}+c_{2} C E P R_{t}+c_{3} C E P R_{t} V_{i t}+e_{i t}
$$

The results are shown in Table 4 (columns 9-10). The CEPR intercept and slope are not significant in any of the cases. We conclude that recession periods do not influence the risk-return trade-off in the European stock markets. This contrasts with the previous results on the role of the FTS episodes. It might be the case, that the insignificance of CEPR recession 
periods in the risk-return trade-off is caused by the sample period where only three recession periods occur.

\subsection{Sovereign debt crisis influence on risk-return trade-off}

We further investigate the influence of the recent European sovereign debt crisis. For this we construct the indicator variable $S D C$ which equals 1 during the sovereign debt crisis. We follow Ehrmann, Osbat, Strasky, and Uuskula (2014) and date the sovereign debt crisis from September 2009 through November 2011. Table 4 (columns 11-12) shows the results from running regression in eq. (7), where we exchange the CEPR indicator in eq. (6) with the $S D C$ indicator.

$$
R_{i t}=c_{0}+c_{1} V_{i t}+c_{2} S D C_{t}+c_{3} S D C_{t} V_{i t}+e_{i t}
$$

The results resemble those from taking recession periods into account, namely that none of the $S D C$ intercept and slope coefficients are significant. So, the negative risk-return trade-off is not caused by the recent sovereign debt crisis.

\section{Flight to gold}

Baur and McDermott (2010) shows that gold is a safe heaven asset. For this reason, we investigate flight from stocks to gold, instead of to bonds. We make use of the returns on the gold futures 100 oz traded on the Chicago Mercantile Exchange. We calculate the FTS $($ gold,$i)$ for each stock market in the same way as we calculate the $F T S(U S, i)$, i.e. we lag the gold returns one day compared to the stock returns, as the gold futures are traded in the US.

[Insert Table 5] 
Table 5 reports the descriptive statistics which are similar to those for the $\operatorname{FTS}(i, i)$ in Table 3. Still, Table 6 shows that the correlation coefficients between $F T S(i, i)$ and FTS (gold,i) are fairly low (between 0.42 and 0.58 ).

[Insert Table 6]

We show the results from running risk-return regressions for each of the stock markets, taking flight to gold into account as follows:

$$
R_{i t}=c_{0}+c_{1} V_{i t}+c_{2} F T S(\text { gold }, i)_{t}+c_{3} F T S(\text { gold }, i)_{t} V_{i t}+e_{i t}
$$

\section{[Insert Table 7]}

Table 7 holds the results (columns 3-4). For reference, we also show the risk-return regressions for the bond FTS variable $(F T S(i, i))$ according to eq. (3) (columns 1-2). The risk-return regressions show a similar picture, no matter if we consider flight to bonds or flight to gold. The explanatory power is slightly lower for the gold FTS regressions than for the bond FTS regressions. We confirm the findings of Baur and McDermott (2010) that gold acts as a safe asset.

\section{Conclusion}

In this paper we investigate flight-to-safety from stocks to bonds in seven European markets. We adopt a quantile regression approach to identify flight-to-safety episodes. Our results show evidence that accounting for flight-to-safety is important in the analysis of the intertemporal risk-return trade-off in European stock markets. The simple risk-return trade-off on the European stock markets is negative. The negative trade-off is caused by flight-to-safety episodes: During normal periods (i.e. in periods outside flight-to-safety episodes), the risk-return trade-off relation is positive, though 
not always significant. On the other hand, during flight-to-safety episodes the aforementioned relation becomes significantly negative. The effects of flight-to-safety episodes on the risk-return trade-off are qualitatively similar across definitions of flight-to-safety episodes; namely own country flightto-safety episodes, flight from own country stock market to the US bond market, or US flight-to-safety. The strength of the trade-off is strongest for own country flight-to-safety episodes. The risk-return trade-off on the European stock markets are not significantly influenced by recession periods or the recent sovereign debt crisis. When considering flight-to-safety to gold instead of to bonds, the main results hold although the explanatory power of the regressions drops.

\section{References}

Aslanidis, N., and C. Christiansen (2014): "Quantiles of the Realized Stock - Bond Correlation and Links to the Macroeconomy," Journal of Empirical Finance, 28, 321 - 331.

Baele, L., G. Bekaert, K. Inghelbrecht, and M. Wei (2015): "Flight to Safety," Working Paper, SSRN.

Baur, D. G., And B. M. Lucey (2009): "Flights and Contagion - An Empirical Analysis of StockâĂŞBond Correlations ," Journal of Financial Stability, 5(4), $339-352$.

Baur, D. G., and T. K. McDermott (2010): "Is Gold a Safe Haven? International Evidence," Journal of Banking and Finance, 34(8), 1886 1898.

Bekaert, G., E. Engstrom, and Y. Xing (2009): "Risk, Uncertainty, and Asset Prices," Journal of Financial Economics, 91(1), 59 - 82. 
Cao, N., And V. Galvani (2016): "Momentum and Market Instability," Working Paper, SSRN.

Ciner, C., C. Gurdgiev, and B. M. Lucey (2013): "Hedges and safe havens: An examination of stocks, bonds, gold, oil and exchange rates," International Review of Financial Analysis, 29, 202 - 211.

Ehrmann, M., C. Osbat, J. Strasky, and L. Uuskula (2014): "The Euro Exchange Rate during the European Sovereign Debt Crisis âĂŞ Dancing to its own Tune?," Journal of International Money and Finance, 49, $319-339$.

Ghysels, E., P. Guerin, and M. Marcellino (2014): "Regime Switches in the Risk-Return Trade-Off ," Journal of Empirical Finance, 28, 118 138.

Ghysels, E., A. Plazzi, and R. Valkanov (2016): "The Risk-Return Relationship and Financial Crises," Working Paper, SSRN.

Granger, C. W. J. (1969): "Investigating Causal Relations by Econometric Models and Cross-spectral Methods," Econometrica, 37(3), 424-438.

Lettau, M., And S. C. Ludvigson (2010): “\{CHAPTER 11 - Measuring and Modeling Variation in the Risk-Return Trade-off," in Handbook of Financial Econometrics: Tools and Techniques, ed. by Y. Ait-Sahalia, and L. P. Hansen, vol. 1 of Handbooks in Finance, pp. 617 - 690. NorthHolland, San Diego.

Newey, W., And K. D. West (1987): "A Simple, Positive Semi-Definite, Heteroskedasticity and Autocorrelation Consistent Covariance Matrix," Econometrica, 55(3), 703-708.

Vayanos, D. (2004): "Flight to Quality, Flight to Liquidity,and the Pricing of Risk," Working Paper, NBER. 
ViceirA, L. M. (2012): "Bond Risk, Bond Return Volatility, and the Term Structure of Interest Rates," International Journal of Forecasting, 28(1), $97-117$. 
Table 1: Descriptive statistics for monthly stock markets

\begin{tabular}{lrrrrrrr} 
Stock returns & France & Germany & Italy & Neth. & Spain & Sweden & UK \\
\hline Mean & 0.72 & 0.62 & 0.47 & 0.70 & 0.76 & 0.74 & 0.69 \\
Std. Dev. & 5.04 & 5.27 & 6.09 & 5.19 & 5.61 & 4.21 & 4.03 \\
Skewness & -0.54 & -0.83 & 0.13 & -1.33 & -0.41 & -0.92 & -0.67 \\
Kurtosis & 3.62 & 5.21 & 3.52 & 7.10 & 3.67 & 5.28 & 4.00 \\
\hline & & & & & & & \\
Stock realized volatility & France & Germany & Italy & Neth. & Spain & Sweden & UK \\
\hline Mean & 5.11 & 4.81 & 5.74 & 4.75 & 5.36 & 4.17 & 4.28 \\
Std. Dev. & 2.51 & 2.62 & 2.72 & 2.85 & 2.56 & 2.35 & 2.37 \\
Skewness & 2.16 & 2.43 & 1.78 & 2.25 & 1.81 & 2.52 & 2.56 \\
Kurtosis & 10.40 & 14.82 & 8.55 & 10.62 & 8.57 & 12.43 & 14.08 \\
\hline
\end{tabular}


Table 2: Descriptive statistics for monthly FTS variables

\begin{tabular}{lrrrrrrrr} 
FTS(i,i) & France & Germany & Italy & Neth. & Spain & Sweden & UK & US \\
\hline Mean & 0.050 & 0.050 & 0.050 & 0.050 & 0.050 & 0.050 & 0.049 & 0.051 \\
Std. Dev. & 0.052 & 0.052 & 0.058 & 0.053 & 0.052 & 0.049 & 0.056 & 0.054 \\
Skewness & 0.98 & 1.06 & 1.30 & 1.45 & 1.14 & 1.10 & 1.25 & 1.13 \\
Kurtosis & 3.42 & 3.66 & 4.39 & 6.28 & 4.11 & 4.14 & 4.58 & 3.94 \\
\hline \multicolumn{1}{r}{} & & & & & & & UK \\
FTS(US,i) & France & Germany & Italy & Neth. & Spain & Sweden & 0.049 \\
Mean & 0.050 & 0.049 & 0.050 & 0.050 & 0.050 & 0.049 & 0.051 \\
Std. Dev. & 0.051 & 0.052 & 0.053 & 0.051 & 0.053 & 0.053 & 1.15 \\
Skewness & 1.06 & 1.07 & 1.03 & 1.05 & 1.06 & 1.17 & 4.19 \\
Kurtosis & 3.90 & 3.81 & 3.60 & 3.61 & 3.54 & 4.24 & 4.15
\end{tabular}


Figure 1: FTS time series
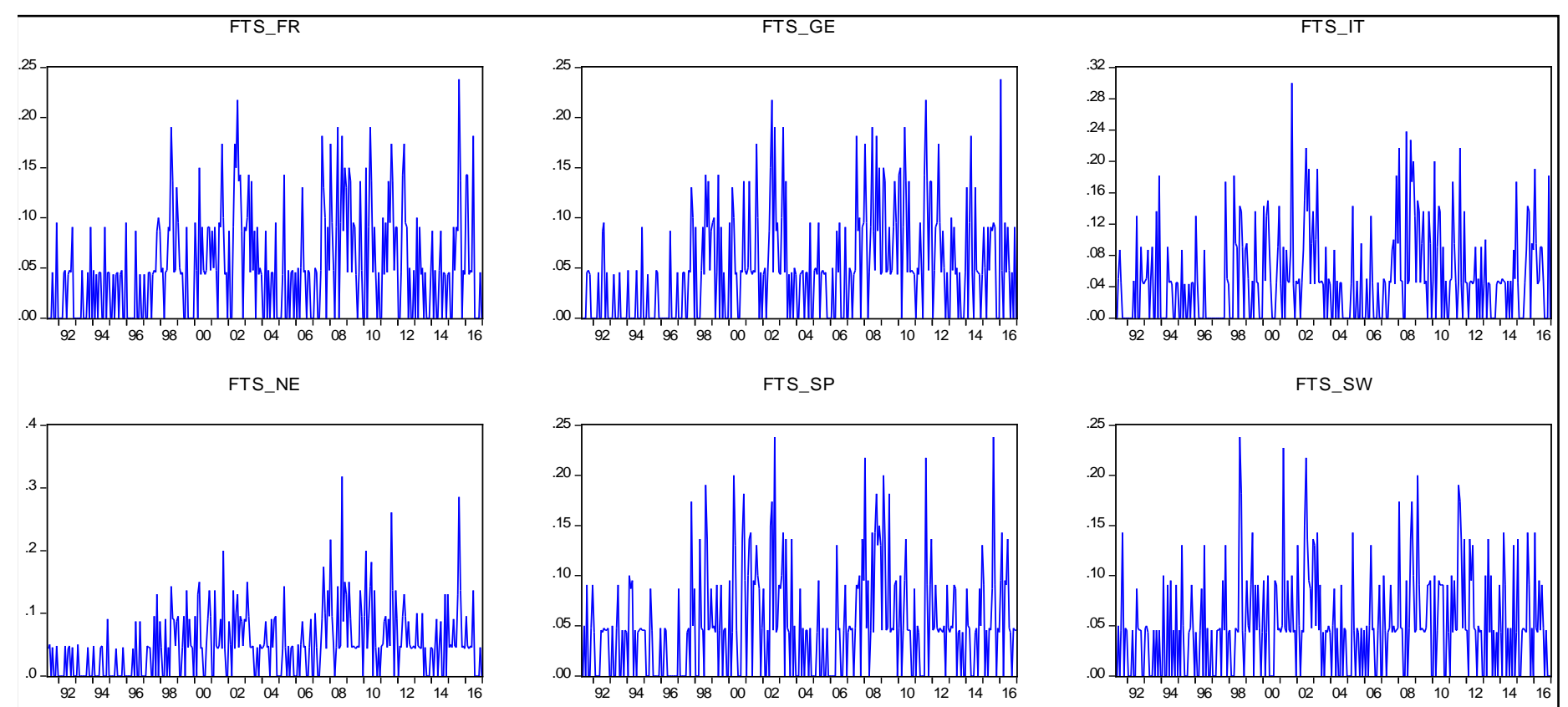

FTS_SP

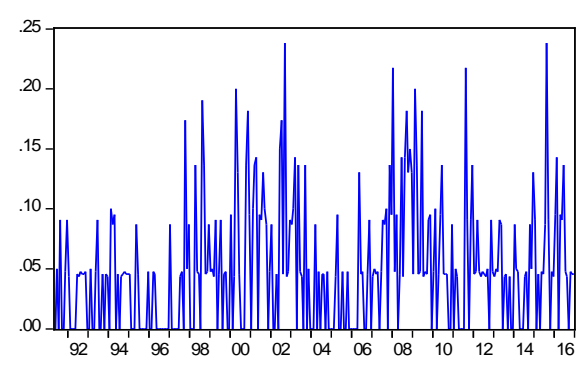

FTS_SW

FTS UK
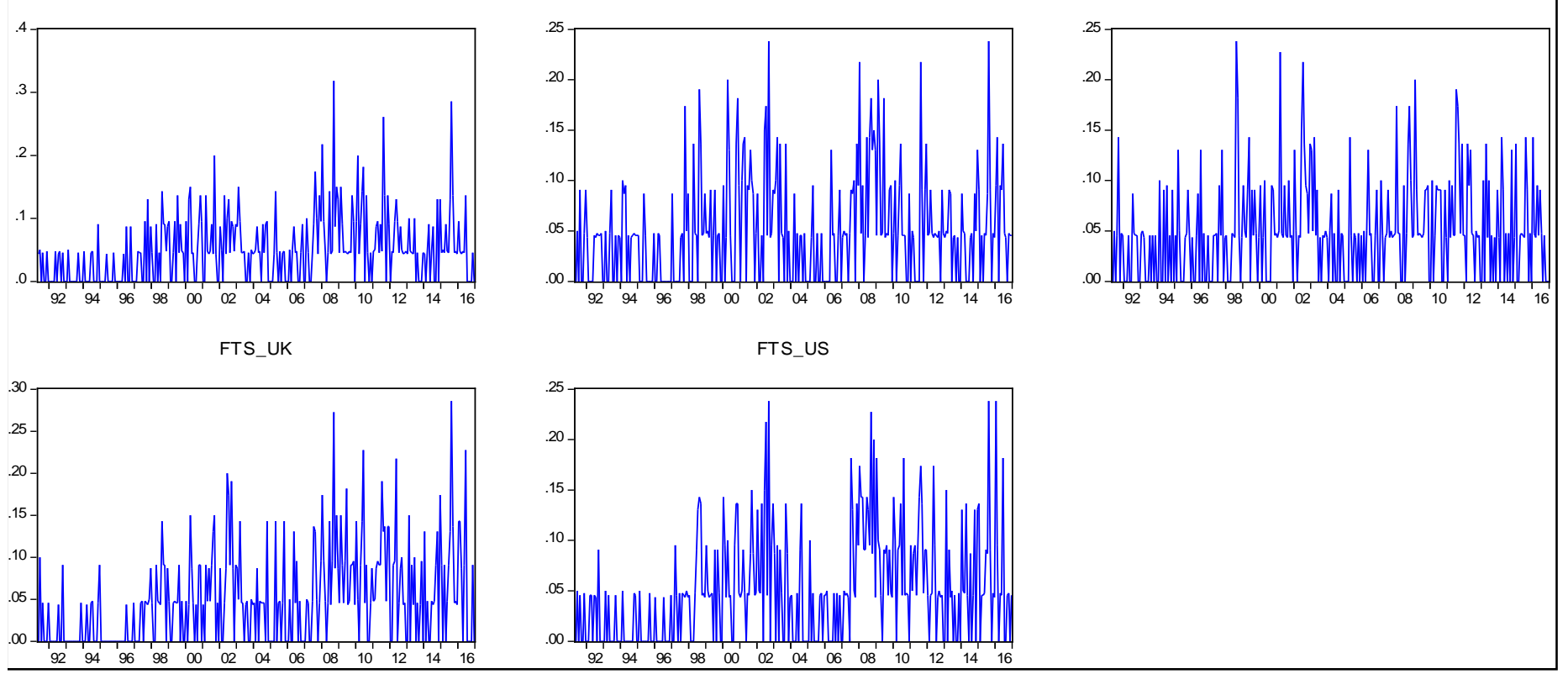
Table 3: Correlations for monthly FTS variables

Panel A: FTS(i,i) and FTS(US,i)

\begin{tabular}{|c|c|c|c|c|c|c|}
\hline France & Germany & Italy & Neth. & Spain & Sweden & UK \\
\hline 0.71 & 0.76 & 0.72 & 0.78 & 0.68 & 0.73 & 0.7 \\
\hline
\end{tabular}

Panel B: FTS(i,i) and FTS(i,i)

\begin{tabular}{r|rrrrrrrr} 
& France & Germany & Italy & Neth. & Spain & Sweden & UK & US \\
\cline { 2 - 8 } France & 1.00 & 0.70 & 0.63 & 0.70 & 0.66 & 0.61 & 0.73 & 0.62 \\
Germany & & 1.00 & 0.60 & 0.70 & 0.57 & 0.65 & 0.66 & 0.67 \\
Italy & & & 1.00 & 0.68 & 0.66 & 0.55 & 0.62 & 0.53 \\
Neth. & & & & 1.00 & 0.64 & 0.60 & 0.71 & 0.64 \\
Spain & & & & & 1.00 & 0.51 & 0.63 & 0.57 \\
Sweden & & & & & & 1.00 & 0.57 & 0.54 \\
UK & & & & & & & 1.00 & 0.65 \\
US & & & & & & & & \\
\end{tabular}

Panel C: FTS(US,i) and FTS(US,i)

\begin{tabular}{r|rrrrrrr} 
& France & Germany & Italy & Neth. & Spain & Sweden & UK \\
\cline { 2 - 7 } France & 1.00 & 0.66 & 0.68 & 0.71 & 0.67 & 0.68 & 0.75 \\
Germany & & 1.00 & 0.62 & 0.69 & 0.64 & 0.66 & 0.64 \\
Italy & & & 1.00 & 0.63 & 0.69 & 0.61 & 0.65 \\
Neth. & & & & 1.00 & 0.66 & 0.66 & 0.69 \\
Spain & & & & & 1.00 & 0.63 & 0.65 \\
Sweden & & & & & & 1.00 & 0.66 \\
UK & & & & & & & 1.00
\end{tabular}


Table 4: Risk-return regressions for stocks

\begin{tabular}{|c|c|c|c|c|c|c|c|c|c|c|c|c|}
\hline France & coef & t-stat & coef & t-stat & coef & t-stat & coef & t-stat & coef & t-stat & coef & t-stat \\
\hline Intercept & 4.74 & 9.40 & 1.55 & 1.39 & 2.47 & 2.25 & 1.82 & 1.89 & 5.02 & 7.57 & 4.57 & 8.32 \\
\hline V & -0.79 & -7.72 & 0.41 & 1.39 & 0.10 & 0.33 & 0.19 & 0.79 & -0.85 & -6.00 & -0.75 & -6.52 \\
\hline FTS(i,i) & & & -17.63 & -2.17 & & & & & & & & \\
\hline FTS $(i, i) * V$ & & & -6.02 & -3.52 & & & & & & & & \\
\hline FTS(US,i) & & & & & -18.07 & -1.95 & & & & & & \\
\hline FTS(US,i)*V & & & & & -4.06 & -2.15 & & & & & & \\
\hline FTS(US,US) & & & & & & & 3.05 & 0.37 & & & & \\
\hline FTS(US,US)*V & & & & & & & -6.55 & -3.90 & & & & \\
\hline CEPR & & & & & & & & & -0.82 & -0.63 & & \\
\hline CEPR*V & & & & & & & & & 0.19 & 0.76 & & \\
\hline SDC & & & & & & & & & & & 1.96 & 1.56 \\
\hline $\mathrm{SDC} * \mathrm{~V}$ & & & & & & & & & & & -0.34 & -1.51 \\
\hline R2 adj & 0.15 & & 0.34 & & 0.27 & & 0.30 & & 0.15 & & 0.15 & \\
\hline
\end{tabular}

\begin{tabular}{lrrrrrrrrrrrr} 
Germany & coef & t-stat & coef & t-stat & coef & t-stat & coef & t-stat & coef & t-stat & coef & t-stat \\
\hline Intercept & 4.40 & 8.49 & 1.36 & 1.84 & 1.31 & 1.68 & 0.89 & 1.20 & 5.08 & 7.06 & 4.22 & 7.74 \\
V & -0.79 & -7.09 & 0.42 & 2.10 & 0.47 & 2.16 & 0.46 & 2.38 & -0.93 & -5.75 & -0.76 & -6.33 \\
FTS $(\mathrm{i}, \mathrm{i})$ & & & -3.20 & -0.43 & & & & & & & & \\
FTS $(\mathrm{i}, \mathrm{i}){ }^{*} \mathrm{~V}$ & & & -8.30 & -5.88 & & & & & & & &
\end{tabular}

$\mathrm{FTS}(U S, i)$

FTS(US,i)*V

FTS(US,US)

$-9.14 \quad-1.12$

$-7.97 \quad-5.39$

FTS(US,US)*V

$18.45 \quad 2.24$

$-10.69 \quad-6.52$

CEPR

CEPR*V

$-2.11-1.81$

SDC

$0.41 \quad 1.49$

SDC*V

R2 adj

0.15

0.36

0.39

0.38

$2.43 \quad 1.79$

$-0.34 \quad-1.07$

Italy

Intercept

coef t-stat

coef t-stat coef t-stat coef t-stat coef t-stat coef t-stat

$$
\mathrm{V}
$$

FTS $(\mathrm{i}, \mathrm{i})$

$\mathrm{FTS}(\mathrm{i}, \mathrm{i}) * \mathrm{~V}$

FTS(US,i)

$\mathrm{FTS}(\mathrm{US}, \mathrm{i}) * \mathrm{~V}$

FTS(US,US)

FTS(US,US)*V

$\begin{array}{llllllllllll}4.30 & 6.74 & 0.47 & 0.50 & -0.74 & -0.68 & 1.52 & 1.36 & 4.41 & 6.79 & 4.06 & 5.61\end{array}$

\section{CEPR}

CEPR*V

$\begin{array}{ll}0.35 & 0.17\end{array}$

\begin{tabular}{|c|c|c|c|c|c|c|c|c|c|}
\hline \multirow[t]{9}{*}{-0.67} & -5.60 & 0.54 & 2.40 & 0.86 & 3.39 & 0.20 & 0.90 & -0.71 & -5.43 \\
\hline & & -22.49 & -2.46 & & & & & & \\
\hline & & -5.15 & -3.88 & & & & & & \\
\hline & & & & -13.85 & -1.12 & & & & \\
\hline & & & & -8.10 & -4.15 & & & & \\
\hline & & & & & & 4.97 & 0.47 & & \\
\hline & & & & & & -6.86 & -3.94 & & \\
\hline & & & & & & & & 0.35 & 0.17 \\
\hline & & & & & & & & 0.05 & .17 \\
\hline
\end{tabular}

SDC

$2.02 \quad 1.41$

SDC*V

R2 adj

0.09

0.30

0.33

0.22

$\begin{array}{ll}-0.41 & -1.57\end{array}$

0.08 


\begin{tabular}{|c|c|c|c|c|c|c|c|c|c|c|c|c|}
\hline Netherlands & coef & t-stat & coef & t-stat & coef & t-stat & coef & t-stat & coef & t-stat & coef & t-stat \\
\hline Intercept & 4.93 & 7.33 & 2.64 & 2.51 & 1.98 & 3.32 & 2.35 & 2.48 & 4.63 & 8.37 & 4.88 & 6.84 \\
\hline V & -0.89 & -5.76 & 0.12 & 0.39 & 0.29 & 1.67 & 0.12 & 0.42 & -0.82 & -6.94 & -0.88 & -5.24 \\
\hline FTS(i,i) & & & -11.26 & -1.47 & & & & & & & & \\
\hline $\mathrm{FTS}(\mathrm{i}, \mathrm{i}) * \mathrm{~V}$ & & & -5.95 & -4.02 & & & & & & & & \\
\hline FTS(US,i) & & & & & -5.04 & -0.56 & & & & & & \\
\hline $\mathrm{FTS}(\mathrm{US}, \mathrm{i}) * \mathrm{~V}$ & & & & & -7.52 & -5.46 & & & & & & \\
\hline FTS(US,US) & & & & & & & 2.28 & 0.36 & & & & \\
\hline FTS(US,US)*V & & & & & & & -7.07 & -5.00 & & & & \\
\hline CEPR & & & & & & & & & 0.90 & 0.65 & & \\
\hline CEPR*V & & & & & & & & & -0.19 & -0.59 & & \\
\hline SDC & & & & & & & & & & & 0.96 & 0.53 \\
\hline $\mathrm{SDC} * \mathrm{~V}$ & & & & & & & & & & & -0.16 & -0.58 \\
\hline $\mathrm{R} 2 \mathrm{adj}$ & 0.24 & & 0.44 & & 0.42 & & 0.41 & & 0.24 & & 0.23 & \\
\hline
\end{tabular}

\begin{tabular}{|c|c|c|c|c|c|c|c|c|c|c|c|c|}
\hline Spain & coef & t-stat & coef & t-stat & coef & t-stat & coef & t-stat & coef & t-stat & coef & t-stat \\
\hline Intercept & 5.04 & 8.56 & 1.93 & 2.02 & 2.09 & 2.31 & 3.09 & 3.02 & 5.26 & 7.92 & 4.96 & 7.60 \\
\hline V & -0.80 & -7.31 & 0.30 & 1.19 & 0.26 & 1.12 & -0.05 & -0.22 & -0.85 & -6.66 & -0.78 & -6.09 \\
\hline FTS(i,i) & & & -13.33 & -1.30 & & & & & & & & \\
\hline $\mathrm{FTS}(\mathrm{i}, \mathrm{i}) * \mathrm{~V}$ & & & -6.13 & -3.10 & & & & & & & & \\
\hline FTS(US,i) & & & & & -18.88 & -2.10 & & & & & & \\
\hline $\mathrm{FTS}(\mathrm{US}, \mathrm{i}) * \mathrm{~V}$ & & & & & -5.19 & -2.77 & & & & & & \\
\hline FTS(US,US) & & & & & & & -10.80 & -1.02 & & & & \\
\hline $\mathrm{FTS}(\mathrm{US}, \mathrm{US}) * \mathrm{~V}$ & & & & & & & -4.28 & -2.25 & & & & \\
\hline CEPR & & & & & & & & & -0.85 & -0.50 & & \\
\hline CEPR*V & & & & & & & & & 0.16 & 0.62 & & \\
\hline SDC & & & & & & & & & & & 0.63 & 0.47 \\
\hline $\mathrm{SDC} * \mathrm{~V}$ & & & & & & & & & & & -0.12 & -0.69 \\
\hline $\mathrm{R} 2 \mathrm{adj}$ & 0.13 & & 0.29 & & 0.30 & & 0.23 & & 0.12 & & 0.12 & \\
\hline
\end{tabular}

\begin{tabular}{|c|c|c|c|c|c|c|c|c|c|c|c|c|}
\hline Sweden & coef & t-stat & coef & t-stat & coef & t-stat & coef & t-stat & coef & t-stat & coef & t-stat \\
\hline Intercept & 4.22 & 10.37 & 2.21 & 2.31 & 1.87 & 2.00 & 2.63 & 3.44 & 4.36 & 8.32 & 4.33 & 10.03 \\
\hline V & -0.84 & -8.41 & 0.29 & 0.89 & 0.24 & 0.79 & -0.09 & -0.36 & -0.89 & -6.71 & -0.84 & -7.96 \\
\hline $\mathrm{FTS}(\mathrm{i}, \mathrm{i})$ & & & -26.12 & -3.11 & & & & & & & & \\
\hline $\mathrm{FTS}(\mathrm{i}, \mathrm{i}) * \mathrm{~V}$ & & & -4.99 & -2.21 & & & & & & & & \\
\hline FTS(US,i) & & & & & -13.22 & -1.74 & & & & & & \\
\hline FTS(US,i)*V & & & & & -5.34 & -2.51 & & & & & & \\
\hline FTS(US,US) & & & & & & & -4.46 & -0.53 & & & & \\
\hline FTS(US,US)*V & & & & & & & -4.68 & -2.30 & & & & \\
\hline CEPR & & & & & & & & & -0.34 & -0.48 & & \\
\hline CEPR*V & & & & & & & & & 0.17 & 1.02 & & \\
\hline SDC & & & & & & & & & & & -1.43 & -1.24 \\
\hline SDC*V & & & & & & & & & & & 0.15 & 0.60 \\
\hline $\mathrm{R} 2$ adj & 0.21 & & 0.45 & & 0.40 & & 0.33 & & 0.21 & & 0.21 & \\
\hline
\end{tabular}




\begin{tabular}{|c|c|c|c|c|c|c|c|c|c|c|c|c|}
\hline UK & coef & t-stat & coef & t-stat & coef & t-stat & coef & t-stat & coef & t-stat & coef & t-stat \\
\hline Intercept & 3.40 & 8.43 & 1.31 & 1.61 & 1.46 & 2.60 & 1.37 & 1.87 & 3.72 & 9.24 & 3.27 & $\overline{7.63}$ \\
\hline V & -0.63 & -5.77 & 0.26 & 0.99 & 0.32 & 1.69 & 0.26 & 1.13 & -0.75 & -6.74 & -0.61 & -5.07 \\
\hline $\mathrm{FTS}(\mathrm{i}, \mathrm{i})$ & & & -3.96 & -0.73 & & & & & & & & \\
\hline $\mathrm{FTS}(\mathrm{i}, \mathrm{i}) * \mathrm{~V}$ & & & -5.33 & -3.39 & & & & & & & & \\
\hline FTS(US,i) & & & & & -16.90 & -2.84 & & & & & & \\
\hline $\mathrm{FTS}(\mathrm{US}, \mathrm{i}) * \mathrm{~V}$ & & & & & -4.57 & -4.03 & & & & & & \\
\hline FTS(US,US) & & & & & & & -5.64 & -0.98 & & & & \\
\hline FTS(US,US)*V & & & & & & & -5.16 & -3.82 & & & & \\
\hline CEPR & & & & & & & & & -0.09 & -0.09 & & \\
\hline CEPR*V & & & & & & & & & 0.21 & 0.78 & & \\
\hline SDC & & & & & & & & & & & 2.86 & 2.11 \\
\hline$S D C * V$ & & & & & & & & & & & -0.44 & -1.66 \\
\hline $\mathrm{R} 2$ adj & 0.14 & & 0.29 & & 0.33 & & 0.29 & & 0.14 & & 0.14 & \\
\hline
\end{tabular}


Figure 2: CEPR recession indicator and FTS(Germany,Germany)

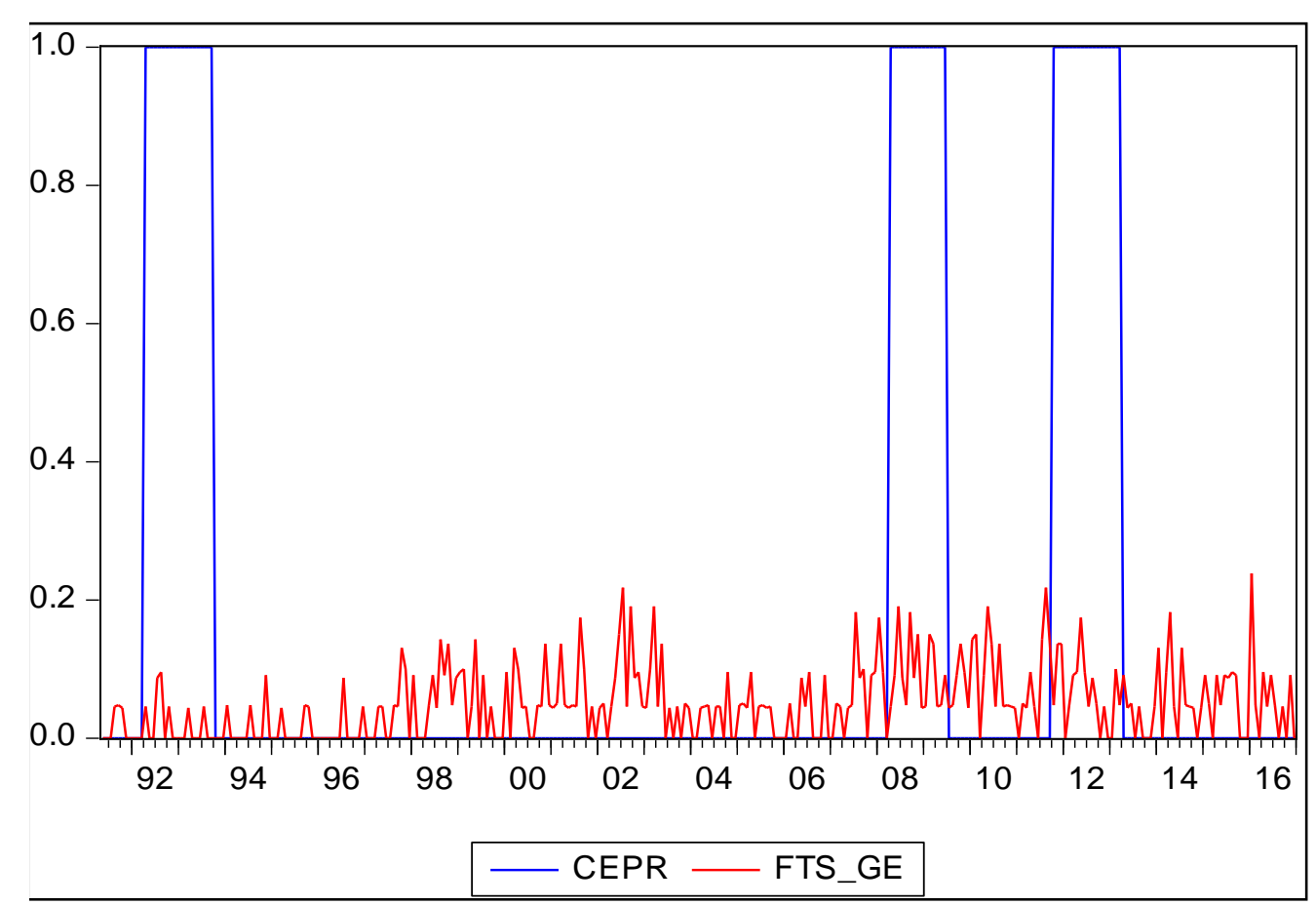


Table 5: Descriptive statistics for monthly gold FTS variables

\begin{tabular}{lrrrrrrrr} 
FTS(gold,i) & France & Germany & Italy & Neth. & Spain & Sweden & UK & US \\
\hline Mean & 0.050 & 0.050 & 0.050 & 0.050 & 0.050 & 0.050 & 0.049 & 0.051 \\
Std. Dev. & 0.052 & 0.051 & 0.054 & 0.053 & 0.051 & 0.051 & 0.050 & 0.052 \\
Skewness & 0.93 & 1.12 & 1.13 & 1.11 & 1.17 & 1.13 & 0.99 & 1.23 \\
Kurtosis & 3.43 & 4.09 & 3.98 & 4.05 & 4.35 & 4.16 & 3.70 & 4.85 \\
\hline
\end{tabular}


Table 6: Correlations for monthly gold FTS variables

Panel A: FTS(i,i) and FTS(gold,i)

\begin{tabular}{|c|c|c|c|c|c|c|c|}
\hline & France & Germany & Italy & Neth. & Spain & Sweden & UK \\
\hline Gold & 0.55 & 0.51 & 0.58 & 0.56 & 0.56 & 0.58 & 0.42 \\
\hline
\end{tabular}

Panel B: FTS(gold,i) and FTS(gold,i)

\begin{tabular}{r|rrrrrrr} 
& France & Germany & Italy & Neth. & Spain & Sweden & UK \\
\cline { 2 - 8 } France & 1.00 & 0.50 & 0.53 & 0.45 & 0.48 & 0.44 & 0.52 \\
Germany & & 1.00 & 0.71 & 0.72 & 0.76 & 0.71 & 0.69 \\
Italy & & & 1.00 & 0.69 & 0.74 & 0.66 & 0.71 \\
Neth. & & & & 1.00 & 0.72 & 0.71 & 0.64 \\
Spain & & & & & 1.00 & 0.69 & 0.74 \\
Sweden & & & & & & 1.00 & 0.62 \\
UK & & & & & & & 1.00
\end{tabular}


Table 7: Risk-return regressions for stocks for gold FTS

\begin{tabular}{lrrrr} 
France & coef & t-stat & coef & t-stat \\
\hline Intercept & 1.55 & 1.39 & 2.79 & 3.20 \\
V & 0.41 & 1.39 & 0.02 & 0.10 \\
FTS $(\mathrm{i}, \mathrm{i})$ & -17.63 & -2.17 & & \\
FTS $(\mathrm{i}, \mathrm{i}) * \mathrm{~V}$ & -6.02 & -3.52 & & \\
FTS(gold, $\mathrm{i})$ & & & -13.72 & -1.57 \\
FTS $(\text { gold }, \mathrm{i})^{*} \mathrm{~V}$ & & & -4.76 & -3.08 \\
R2 adj & 0.34 & \multicolumn{2}{c}{0.30} \\
\hline
\end{tabular}

\begin{tabular}{lrrrr} 
Germany & coef & t-stat & coef & t-stat \\
\hline Intercept & 1.36 & 1.84 & 1.80 & 2.50 \\
V & 0.42 & 2.10 & 0.19 & 1.09 \\
FTS(i,i) & -3.20 & -0.43 & & \\
FTS(i,i)*V & -8.30 & -5.88 & & \\
FTS(gold,i) & & & 7.17 & 0.76 \\
FTS(gold,i)*V & & -8.10 & -4.34 \\
R2 adj & 0.36 & 0.32 \\
\hline
\end{tabular}

\begin{tabular}{lrrrr} 
Italy & coef & t-stat & coef & t-stat \\
\hline Intercept & 0.47 & 0.50 & 0.33 & 0.36 \\
V & 0.54 & 2.40 & 0.54 & 2.64 \\
FTS(i,i) & -22.49 & -2.46 & & \\
FTS(i,i)*V & -5.15 & -3.88 & & \\
FTS(gold,i) & & & -8.28 & -0.72 \\
FTS(gold,i)*V & & & -6.96 & -4.84 \\
R2 adj & 0.30 & \multicolumn{3}{c}{0.28} \\
\hline
\end{tabular}

\begin{tabular}{|c|c|c|c|c|}
\hline Netherlands & coef & t-stat & coef & t-stat \\
\hline Intercept & 2.64 & 2.51 & 2.49 & 3.25 \\
\hline V & 0.12 & 0.39 & -0.01 & -0.06 \\
\hline FTS(i,i) & -11.26 & -1.47 & & \\
\hline $\mathrm{FTS}(\mathrm{i}, \mathrm{i}) * \mathrm{~V}$ & -5.95 & -4.02 & & \\
\hline FTS(gold,i) & & & 13.26 & 1.48 \\
\hline FTS(gold,i)*V & & & -7.92 & -5.32 \\
\hline R2 adj & 0.44 & & 0.36 & \\
\hline
\end{tabular}




\begin{tabular}{|c|c|c|c|c|}
\hline Spain & coef & t-stat & coef & t-stat \\
\hline Intercept & 1.93 & 2.02 & 3.82 & 3.15 \\
\hline V & 0.30 & 1.19 & -0.10 & -0.37 \\
\hline $\mathrm{FTS}(\mathrm{i}, \mathrm{i})$ & -13.33 & -1.30 & & \\
\hline $\mathrm{FTS}(\mathrm{i}, \mathrm{i}) * \mathrm{~V}$ & -6.13 & -3.10 & & \\
\hline FTS(gold,i) & & & -29.04 & -2.42 \\
\hline FTS(gold,i)*V & & & -3.21 & -1.55 \\
\hline $\mathrm{R} 2 \mathrm{adj}$ & \multicolumn{2}{|c|}{0.29} & \multicolumn{2}{|l|}{0.29} \\
\hline Sweden & coef & t-stat & coef & t-stat \\
\hline Intercept & 2.21 & 2.31 & 2.74 & 4.80 \\
\hline V & 0.29 & 0.89 & -0.04 & -0.23 \\
\hline $\mathrm{FTS}(\mathrm{i}, \mathrm{i})$ & -26.12 & -3.11 & & \\
\hline $\mathrm{FTS}(\mathrm{i}, \mathrm{i}) * \mathrm{~V}$ & -4.99 & -2.21 & & \\
\hline FTS(gold,i) & & & -8.43 & -1.09 \\
\hline FTS(gold,i)*V & & & -5.46 & -3.27 \\
\hline $\mathrm{R} 2 \mathrm{adj}$ & \multicolumn{2}{|c|}{0.45} & \multicolumn{2}{|l|}{0.36} \\
\hline UK & coef & t-stat & coef & t-stat \\
\hline Intercept & 1.31 & 1.61 & 1.73 & 2.45 \\
\hline $\mathrm{V}$ & 0.26 & 0.99 & 0.06 & 0.30 \\
\hline $\mathrm{FTS}(\mathrm{i}, \mathrm{i})$ & -3.96 & -0.73 & & \\
\hline $\mathrm{FTS}(\mathrm{i}, \mathrm{i}) * \mathrm{~V}$ & -5.33 & -3.39 & & \\
\hline FTS(gold,i) & & & 4.11 & 0.48 \\
\hline FTS(gold,i)*V & & & -5.67 & -2.69 \\
\hline $\mathrm{R} 2 \mathrm{adj}$ & \multicolumn{2}{|c|}{0.29} & \multicolumn{2}{|l|}{0.24} \\
\hline
\end{tabular}


2017-22: Jakob Guldbæk Mikkelsen: Testing for time-varying loadings in dynamic factor models

2017-23: $\quad$ Roman Frydman, Søren Johansen, Anders Rahbek and Morten Nyboe Tabor: The Qualitative Expectations Hypothesis: Model Ambiguity, Concistent Representations of Market Forecasts, and Sentiment

2017-24: Giorgio Mirone: Inference from the futures: ranking the noise cancelling accuracy of realized measures

2017-25: $\quad$ Massimiliano Caporin, Gisle J. Natvik, Francesco Ravazzolo and Paolo Santucci de Magistris: The Bank-Sovereign Nexus: Evidence from a nonBailout Episode

2017-26: Mikkel Bennedsen, Asger Lunde and Mikko S. Pakkanen: Decoupling the shortand long-term behavior of stochastic volatility

2017-27: $\quad$ Martin M. Andreasen, Jens H.E. Christensen and Simon Riddell: The TIPS Liquidity Premium

2017-28: Annastiina Silvennoinen and Timo Teräsvirta: Consistency and asymptotic normality of maximum likelihood estimators of a multiplicative time-varying smooth transition correlation GARCH model

2017-29: Cristina Amado, Annastiina Silvennoinen and Timo Teräsvirta: Modelling and forecasting WIG20 daily returns

2017-30: Kim Christensen, Ulrich Hounyo and Mark Podolskij: Is the diurnal pattern sufficient to explain the intraday variation in volatility? A nonparametric assessment

2017-31: $\quad$ Martin M. Andreasen, Jens H.E. Christensen and Glenn D. Rudebusch: Term Structure Analysis with Big Data

2017-32: Timo Teräsvirta: Nonlinear models in macroeconometrics

2017-33: Isabel Casas, Eva Ferreira and Susan Orbe: Time-varying coefficient estimation in SURE models. Application to portfolio management

2017-34: Hossein Asgharian, Charlotte Christiansen, Ai Jun Hou and Weining Wang: Long- and Short-Run Components of Factor Betas: Implications for Equity Pricing

2017-35: Juan Carlos Parra-Alvarez, Olaf Posch and Mu-Chun Wang: Identification and estimation of heterogeneous agent models: A likelihood approach

2017-36: Andrés González, Timo Teräsvirta, Dick van Dijk and Yukai Yang: Panel Smooth Transition Regression Models

2017-37: Søren Johansen and Morten Ørregaard Nielsen: Testing the CVAR in the fractional CVAR model

2017-38: Nektarios Aslanidis and Charlotte Christiansen: Flight to Safety from European Stock Markets 